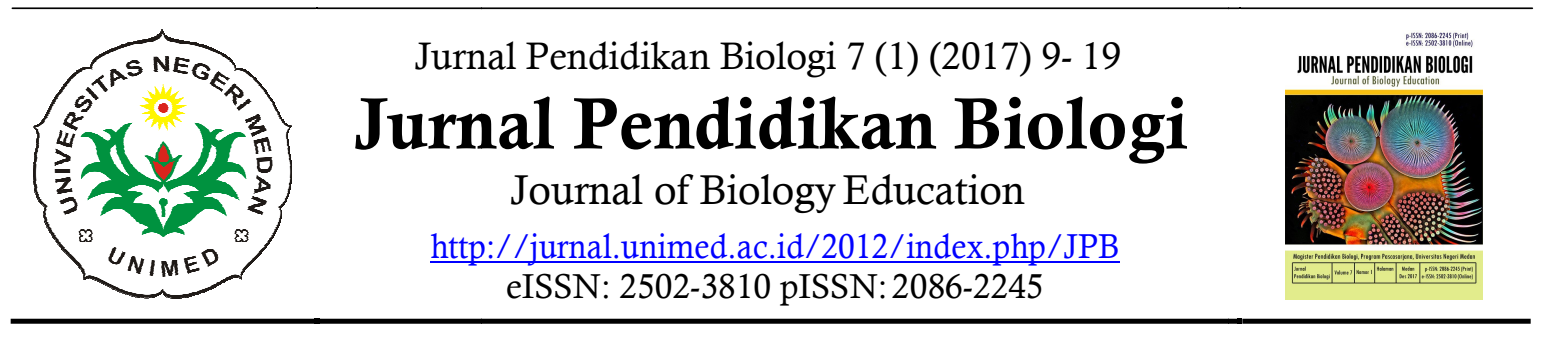

\title{
Pengaruh Strategi Konversi PetaKonsep Terhadap Retensi Mahasiswa Jurusan Pendidikan IPA Biologi Universitas Islam Negeri Mataram
}

\author{
Neneng Agustiningsih* \\ Jurusan Pendidikan IPA Biologi, UIN Mataram, NTB, Indonesia. \\ *Korespondensi: neneng.agustiningsih@uinmataram.ac.id
}

\begin{abstract}
ABSTRAK
This study aims to examine the effect of mind map conversion strategy toward students retention of Biology Education Department in UIN Mataram, year 2016-2017. This research is a Quasi Experiment, using non equivalent control group design with pretest - posttest which performed in two groups of the fourth semester students. Treatment group is class $C$ used mind map conversion strategy, and as control group is class D used a multistrategy, with total of 63 students. The retention instrument uses a mind map scoring sheet. The retention hypothesis was analyzed using t-test by SPSS version 21 . The statistical analysis showed sig.t test $=0,00<0,05$ then $\mathrm{H}_{0}$ is rejected. This mind map conversion strategy hasa significantinfluencetoward the retention of class $C$ students.
\end{abstract}

Keyword : Retention, mind map conversion strategy, Biology Education Department

\section{PENDAHULUAN}

Pembelajaran sepanjang hayat yang dikemukakan oleh Paul Lengrand (1970), jauh sebelum itu Muhammad SAW pernah menyampaikan bahwa belajar memang seharusnya sejak dalam buaian sampai ke liang lahat, minaal Mahdi ilaal lahdi (Suyono, 2011). Pembelajaran dalam perkembangan global di abad 21 menuntut dunia pendidikan untuk selalu mengubah konsep berpikirnya terhadap berbagai rancangan pendidikan dan strategi pembelajaran, sehingga pengetahuan dan keterampilan tersampaikan dengan baik pada mahasiswa, melalui pemerolehan informasi, ide, keterampilan, nilai, cara berpikir, sarana untuk mengekspresikan diri, dan cara-cara belajar bagaimana belajar(learning how tolearn).

Fisiologi Tumbuhan merupakan salah satu cabang ilmu biologi yang membahas konsep dasar masalah fisiologis pada tumbuhan, berupa konsep abstrak meliputi materi proses fundamental pada tumbuhan yang mendukung dari kegiatan praktikum. Menurut Dwijoseputro (1978), luasnya pokok bahasan fisiologi tumbuhan banyak berkaitan serta didukung oleh ilmu-ilmu dasar seperti ilmu kimia (khususnya biokimia) dan fisika, sehingga dibutuhkan pemahaman yang utuh tentang fisiologi tumbuhan. Namun umumnya kegiatan pembelajaran dilakukan hanya mencatat dan menghafal, hal ini sangat mempengaruhi daya tarik dan daya ingat 
konsep Fisiologi Tumbuhan, yang secara tidak langsung akan menambah kebingungan mahasiswa terhadap pemahaman konsep saat praktikum dilaksanakan, dimana tinggi rendahnya prestasi belajar mahasiswa dapat menjadi indikator kualitas pendidikan Fisiologi Tumbuhan di kelas.

Hasil belajar Fisiologi Tumbuhan pada mahasiswa Kelas IV C dan D Semester Genap Tahun Ajaran 2015-2016cukup rendah dengan total 70 mahasiswa, 13 diantaranya mendapat nilai $C$, dan 4 mendapat nila D. Pada saat kegiatan diskusi kelas, mahasiswa tidak dapat memperoleh hubungan utuh pada materi yang dipelajari sehingga mahasiswa tidak terlalu antusias dalam sesi tanya-jawab, menyebabkan kegiatan pembelajaran seperti tidak ada umpan balik positif. Kegiatan diskusi terkesan hanya berlangsung dua arah, antara pemateri dengan penyaji. Untuk itu diperlukan pembaharuan dalam mengajarkan Fisiologi Tumbuhan dengan suatu strategi mengajar yang dapat menggambarkan proses yang terjadi dan keterkaitan antar konsep fisiologi tumbuhan tersebut, salah satu cara yang dapat dilakukan adalah dengan menggunakan strategi konversi peta konsep.

Menurut Ginnis, P. (2008), strategi konversi adalah cara belajar bagi mahasiswa untuk mengkonversikan informasi atau pengetahuan ke dalam bentuk atau format lain. Pelaksaan konversi baru akan dilakukan bila mahasiswa paham akan materi yang dipelajari, melalui aktivitas ini dapat mengungkapkan adanya miskonsepsi dan kesulitan sehingga memberikan pengalaman dalam penilaian diagnostik, membekali mahasiswa dengan belajar mandiri dan keterampilan revisi. Strategi konversi dapat dilakukan pada berbagai macam informasi yang diperoleh dan dikonversi. Dalam penelitian ini informasi atau pengetahuan diperoleh dari slide power point $(\mathrm{PPt})$ dan video dikonversi pada program peta konsep. Strategi ini merupakan pemetaan konsep melalui pemberian tugas kognitif menantang yang membutuhkan berbagai proses berpikir kritis, seperti menilai dan mengklasifikasi informasi, mengenali pola, meng identifikasi dan memprioritaskan ide utama, membandingkan dan membedakan, mengidentifikasi hubungan, dan berpikir logis. Proses ini menuntut mahasiswa untuk menguraikan dan mengatur informasi dengan cara yang bermakna, yang tidak dapat direalisasikan hanya dengan menghafal fakta tanpa memahami maknanya. Peta konsep memegang peranan penting dalam belajar bermakna.

Dalam pembelajaran menggunakan strategi konversi peta konsep terdapat tiga langkah unggulan yaitu mencatat (notetaking), meringkas (summarizing), dan mengkaji ulang (reviewing) materi yang telah diberikan, oleh karena itu sangat efektif untuk mengorganisasikan informasi yang masuk ke otak, sekaligus membantu memperkuat daya ingatnya (Adtya, D. M., 2015). Dengan adanya variasi strategi pembelajaran berupa konversi peta konsep, diharapkan mahasiswa mudah mengingat dan paham serta meningkatkan retensi belajarpada materi Mata Kuliah Fisiologi Tumbuhan.

\section{METODE PENELITIAN}

Populasi penelitian ini adalah seluruh mahasiswa semester IV yang terdiri atas empat kelas dengan total 160 mahasiswa, dengan tiap kelasnya terdiri dari 40 mahasiswa. Sampel dalam penelitian ini adalah mahasiswa kelas IV C dan IV D yang ditentukan dengan cara cluster random sampling dengan cara mengundi. Penelitian ini tergolong eksperimen semu (quasy 
experimental design), menggunakan non posttest. Adapun rancangan penelitian equivalent control group design dengan pretest - $\quad$ terdapat pada Tabel 1.

Tabel 1. Pre-test and Post-test Control Group Design

\begin{tabular}{cccc}
\hline \multicolumn{1}{c}{ Kelompok } & Pre-test & Perlakuan & Pos-test \\
\hline A & $\mathrm{O}_{1}$ & $\mathrm{X}_{1}$ & $\mathrm{O}_{2}$ \\
B & $\mathrm{O}_{4}$ & $\mathrm{X}_{2}$ & $\mathrm{O}_{5}$ \\
\hline Keterangan : & & & \\
A: Kelas Perlakuan (IV C) & $\mathrm{O}_{1}, \mathrm{O}_{4}$ : Nilai pre-test & $\mathrm{X}_{1}$ : Perlakuan strategi konversi peta konsep \\
B: Kelas Kontrol (IV D) & $\mathrm{O}_{2}, \mathrm{O}_{5}$ : Nilai post-test & $\mathrm{X}_{2}$ & :Pembelajaran multistrategi
\end{tabular}

Data retensi diperoleh dari tes membuat peta konsep. Selain instrumen penilaian, terdapat instrumen pembelajaran digunakan berkaitan dengan pelaksanaan pembelajaran, dimana peneliti menyusun Rencana Pembelajaran Semester (RPS) untuk mata kuliah Fisiologi Tumbuhan Semester Genap Tahun Ajaran 2016-2017 yang di dalamnya terdapat materi fitohormon, dan gerak tumbuhan.

\section{Analisis Data}

Penilaian retensi dites dengan tes pembuatan peta konsep menggunakan program Edraw Mind Maping versi 7.Instrumen penilaian retensi diambil dari sumber Novak, J.D \& Gowin D, tahun 1984 yang telah tervalidasi dan reliabel dengan indikator ;1) Hubungan Antar Konsep (Proposisi), untuk setiap proposisi yang sahih diberi skor 1. 2) Hierarki Antar Konsep (Hierarki), untuk setiap hierarki yang sahih diberi skor 5. 3) Kaitan Silang Antar Konsep (Kaitan Silang), untuk setiap kaitan silang yang sahih diberi skor 10 . Sedangkan untuk setiap kaitan silang yang kurang sahih diberi skor 2. 4) Contoh Konsep (Contoh), untuk setiap contoh yang sahih diberi skor 1.

Tes retensi dilakukan penelitian pada Mata Kuliah Fisiologi Tumbuhan materi fitohormon dan gerak pada tumbuhan yang diberikan pada sebelum (pretest) dan sesudah (pretest) penerapan strategi konversi peta konsep, data pretest dan pretest, data tersebut akan dianalisis melalui uji :

1. Uji normalitasnya menggunakan Kolmogorov-Smirnov Test. Dasar pengambilan keputusan sebagai begai berikut;

a. Jika nilai probabilitas (Sig.) (Kolmogorov-Smirnov Z) > 0,05, maka $\mathrm{H}_{0}$ diterima, artinya data terdistribusi normal.

b. Jika nilai probabilitas (Sig.) (Kolmogorov-Smirnov Z) $<0,05$, maka $\mathrm{H}_{0}$ ditolak, artinya data tidak terdistribusi normal.

2. Uji homogenitas menggunakan uji Levens. Pengujian hipotesis dilakukan dengan uji t pada taraf signifikan $\boldsymbol{\alpha}=$ 0,05 , semua data akan dianalisis dengan program SPSS 21 for Windows. Adapun kriteria dalam pengambilan keputusan adalah :

a. Jika nilai probabilitas (Sig.) $>0,05$, berarti data varians adalah homogen.

b. Jika nilai probabilitas (Sig.) $<0,05$, berarti data varians adalah tidak homogen.

\section{HASIL DAN PEMBAHASAN}

\section{Pembelajaran Strategi Konversi Peta Konsepdan Multistrategi}

Proses keterlaksanaan pembelajaran strategi konversi peta konsep untuk mencapai retensi selama pembelajaran 
berlangsung secara umum dapat dikatakan telah berhasil, dibandingkan dengan retensi mahasiswa pada pembelajaran multistartegi, dimana pada dasarnya pembelajaran strategi konversi peta konsep mengharapkan delapan komponen keterlaksanaan, dengan proses pelaksanaan pembelajaran strategi konversi peta konsep berlangsung selama tujuh kali pertemuan, termasuk di dalamnya prepost dan posttest, dimulai pada tanggal Juni hingga $13 \mathrm{Juli}$ 2017.

Penggunaan Rencana pembelajaran Semester (RPS) pada kelas perlakuan dan kelas kontrol adalah sama, digunakan indikator pada materi fitohormon antara lain; Menjelaskan pengertian hormon (fitohormon), Membedakan hormon, dengan vitamin, dan enzim, Menyebutkan macam-macam fitohormon, Menjelaskan macam-macam fungsi fitohormon, Mendeskripsikan mekanisme kerja fitohormon, dan Mengaitkain kerja fitohormon dengan sistem koordinasi kerja pada tumbuhan. Indikator pada materi gerak tumbuhan, antara lain; Mengintegrasi gerak tumbuhan dengan alquran dan di lingkungan, Menjelaskan pengertian gerak tumbuhan, Membedakan macam-macam gerak tumbuhan, Menyebutkan contoh macam-macam gerak tumbuhan di lingkungan, dan Menghubungkan kerja fitohormon dengan gerak tumbuhan.

Sebelum dilaksanakannya kegiatan penelitian, peneliti memberikan pengenalan pada mahasiswa kelas perlakuan dan kontrol tentang Program Edraw Mind Map versi 7 dan cara penggunaannya sehingga semua mahasiswa dapat menginstal dan menggunakannya, dimana sosialisasi ini dilakukan di luar dari jadwal perkuliahan.

Proses pembelajaran strategi konversi peta konsep pada kelas perlakuan dan multistrategi pada kelas kontrol berlangsung selama tujuh kali pertemuan, termasuk di dalam nya preteset dan posttest, diawali pada tanggal 7 Juni hingga 13 Juli 2017. Pembelajaran multistrategi diberlakukan pada kelas kontrol, yaitu kelas IV D pada penelitian ini, terdiri atas metode presentasi, diskusi, dan sepak bola verbal.Secara ringkas pelaksanaan strategi konversi peta konsep, dan multistrategi terdapat pada Tabel 2.

Tabel 2. Strategi Konversi Peta Konsep, Dan Multistrategi

Startegi Pembelajaran Langkah dalam Pembelajaran

a. Strategi Konversi 1. Dosen menyajikan mekanisme pembelajaran melalui konversi peta Peta Konsep konsep \& penggunaannya

2. Membentuk kelompok heterogen dengan anggota 3-4 orang perkelompok

3. Dosen memberikan tugas kelompok presentasi untuk tiap materi Fisiologi Tumbuhan

4. Presentasi materi oleh perwakilan kelompok melalui slide PPt dan video

5. mahasiswa mengidentifikasi ide pokok atau prinsip yang melingkupi sejumlah konsep (mencatat)

6. mahasiswa mengidentifikasi konsep sekunder dari penjelasan ide pokok suatu materi (meringkas)

7. Dosen membimbing mahasiswa dalam mengolah dan menyusun peta konsep

8. Dosen dan mahasiswa melakukan diskusi kelas terkait materi dan peta konsep (mengkaji ulang/review)

b. Pembelajaran multistrategi
1. Dosen membentuk kelompok heterogen dengan anggota 3-4 orang perkelompok 


\begin{tabular}{ll}
\hline Startegi Pembelajaran & \multicolumn{1}{c}{ Langkah dalam Pembelajaran } \\
\hline 2. & $\begin{array}{l}\text { Dosen memberikan tugas kelompok presentasi untuk tiap materi } \\
\text { Fisiologi Tumbuhan }\end{array}$ \\
3. $\begin{array}{l}\text { Presentasi materi oleh perwakilan kelompok melalui slide PPt dan } \\
\text { video (Presentasi) }\end{array}$ \\
4. $\begin{array}{l}\text { Mahasiswa mencatat konsep esensial dengan membuat peta konsep } \\
\text { bentuk sederhana dan melakukan tanya-jawab pada materi yang } \\
\text { dipresentasikan kepada teman dan dosen (diskusi kelas), pada } \\
\text { pertemuan ke-lima } \\
\text { Dosen pada pertemuan materi Gerak Tumbuhan pada tahap akhir } \\
\text { diskusi kelas akan membentuk } 2 \text { kelompok menjadi Tim A dan B } \\
\text { akam memperebutkan soal dari dosen bertindak sebagai wasit } \\
\text { (sepak bola verbal) pada pertemuan ke-enam }\end{array}$ \\
\hline
\end{tabular}

Serangkaian langkah pembelajaran yang dilaksanakan oleh mahasiswa seperti dalam tabel di atas akan menghasilkan sebuah produk atau hasil berupa peta konsep sederhana berdasarkan materi yang disampaikan oleh dosen dan mahasiswa presentasi makalah melalui video dan materi dalam bentuk slide power point $(\mathrm{PPt})$, dimana materi yang dibahas adalah fitohormon dan gerak tumbuhan. Program Edraw Mind Map versi 7 merupakan program mind map yang menyajikan theme dan template serta clip art dengan pilihan yang bervariasi dan bewarna-warni, dengan disertai contoh penggunaan peta konsep, serta bermacam-macam logodan background dapat menggunakan file gambar atau foto dari gallery sesuai pilihan. Sehingga sangat tepat bagi peserta didik yang baru menggunakan program peta konsep untuk menyusun konsep-konsep pokok dan sekunder dalam pengingatan materi yang dipelajari.

Penggunaan media video pada kelas perlakuan dan kontrol memberikan kontribusi terhadap retensi mahasiswa, hal ini sesuai dengan pendapat Ronal Anderson (1987 ; Asyhar, H. Rayandra 2012), bahwa tujuan penggunaan media video adalah mengembangkan kemampuan kognitif yang menyangkut kemampuan mengenal kembali dan kemampuan memberikan rangsangan berupa gerak dan sensasi, dimana video pembelajaran berisi sejumlah besar informasi, hal ini memungkinkan siswa lebih mudah memenuhi tujuan pembelajaran. senada dengan pendapat Francis M. Dwyer (1978) yaitu video mampu merebut $94 \%$ saluran masuknya pesan atau informasi kedalam jiwa manusia melalui mata dan telinga serta mampu untuk membuat orang pada umumnya mengingat $50 \%$ dari apa yang mereka lihat dan dengar dari tayangan program. Pesan yang disampaikan melalui media video dapat mempengaruhi emosi yang kuat dan juga dapat mencapai hasil cepat yang tidak dimiliki oleh media lain. Menurut Cheppy Riyana (2007) Membantu pemahaman dan ingatan isi materi bagi siswa yang lemah dalam membaca.

Pelaksanaan pembelajaran strategi konversi peta konsep merupakan strategi pertama kali dilaksanakan oleh mahasiswa, yang sebelumnya mahasiswa hanya melaksanakan pembelajaran dengan strategi diskusi kelas, presentasi kelompok dan praktikum pada mata kuliah Fisiologi Tumbuhan. Sehingga mahasiswa sangat antusias dan senang walaupun terdapat kekurangan, diantara nya yaitu : 1) penggunaan leptop; dalam pembuatan peta konsep, dimana tidak semua mahasiswa memiliki leptop, dan tidak semua menguasai secara terampil penggunaan program edraw maindmap versi 7 sehingga pembuatan peta konsep terbatas tidak sampai pada empat penilaian dari indikator 
peta konsep, 2) penguasaan materi; setiap mahasiswa memiliki kemampuan berbeda dalam memahami materi yang dipelajari, khususnya materi Fisiologi yang memiliki konsep yang sangat banyak dan istilah yang hampir mirip, sehingga mahasiswa perlu adanya pengumpulan informasi yang banyak untuk memahami materi, 3) analisis dan pembahasan materi yang abstrak dan komplek; fisiologi tumbuhan mencakup materi proses atau mekanisme fungsional organ pada tubuh tumbuhan, dimana materi yang dipelajari $99 \%$ mempelajari materi abstrak dan komplek sehingga mahasiswa tidak semua dapat memahami secara utuh, sehingga perlunya media yang memfasilitasi untuk menggambarkan materi terkait proses yang terjadi dalam kehidupan tumbuhan.

Pembelajaran multistrategi diberlakukan pada kelas kontrol, yaitu kelas IV D. Adapun strategi yang dilaksanakan di kelas kontrol yaitu : 1) Strategi presentasi kelompok, merupakan startegi yang sangat sering dilakukan pada kebanyakan pembelajaran perguruan tinggi, dimana dosen akan membagi peserta didik menjadi tujuh kelompok heterogen yang terdiri atas 3- 4 orang untuk mengerjakan tugas kelompok berdasarkan materi tugas makalah yang diberikan berdasarkan RPS yang telah diberikan, dan dipresentasikan di depan kelas dengan membuat slide power point dan disertakan video terkait materi yang ditugaskan. 2) Strategi diskusi, salah satu strategi yang biasa dilakukan pada pembelajaran, biasanya strategi ini bersamaan dengan metode ceramah, demontrasi, analisis literasi, atau strategi presentasi. Dalam pelaksanaannya di kelas, dosen ataupun peserta didik akan menyampaikan materi yang akan di bahas di dalam diskusi, dan peserta didik lainnya akan menyampaikan pendapat dan berbagi pendapatnya dengan peserta didik lainnya. 3) Strategi sepak bola verbal, merupakan strategi belajar yang pertama kali dilakukan di kelas kontrol, stategi ini merupakan penguatan pada akhir pembelajaran bertujuan untuk melihat sejauh mana siswa mengingat dan paham materi yang telah diajarkan. Peserta didik akan dibagi menjadi dua kelompok besar dalam kelas, tiap kelompok terdiri atas satu kapten dan sisanya adalah anggota. Guru bertindak sebagai wasit antara dua tim yang bertugas melemparkan soal dan dianggap sebagai bola (soal secara verbal) yang akan diberikan pada tim pertama penerima bola verbal, dan mengatur jalannnya permainnan agar objektif dan lancar, wasit berhak memberikan kartu hijau, kuning dan merah bagi pemain yang melanggar. Bola verbal berisikan pertanyaan dan terdapat 15 pertanyaan uraian yang harus dijawab oleh tim main. Pemberian poin bagi setiap anggota dalam tim yang bisa menjawab sebesar 1-5 point tergantung jenis kesulitan soal yang diberikan. Pemberian point akan ditulis di depan papan agar peserta didik termotivasi, dan aktif dalam pembelajaran.

\section{Retensi Belajar}

Retensibelajar mahasiswa diukur menggunakan tes pembuatan peta konsep pada materi fitohormon dan gerak tumbuhanmenggunakan program edraw mind map versi 7.Berdasarkan data yang diperoleh retensi kelas perlakuan berbeda jauh dengan kelas kontrol. Deskripsi umum mahasiswa secara ringkas dapat dilihat pada Tabel 3. 
Tabel 3. Ringkasan Data Retensi, pada Kelas Strategi Konversi Peta Konsep Dan Kelas Multistrategi

\begin{tabular}{lcc}
\hline \multirow{2}{*}{ Perihal } & \multicolumn{2}{c}{ Retensi } \\
\cline { 2 - 3 } & Kelas Perlakuan & Kelas Kontrol \\
\hline Nilai tertinggi & 93,5 & 71 \\
Nilai terendah & 34 & 13,5 \\
Rerata & 64,7 & 45,6 \\
Standar deviasi & 16,4 & 18,4 \\
\hline
\end{tabular}

Berdasarkan Tabel 3 diketahui bahwa nilai rerata retensi mahasiswa kelas perlakuan yang diajarkan menggunakan strategi konversi peta konseplebih tinggi dibanding kelas kontrol yang diajarkan menggunakan multistrategi. Rerata nilai mahasiswa pada retensi secara signifikan berbeda Hasil retensi nilai tertinggi, terendah dan rerata di sajikan pada Gambar 1.

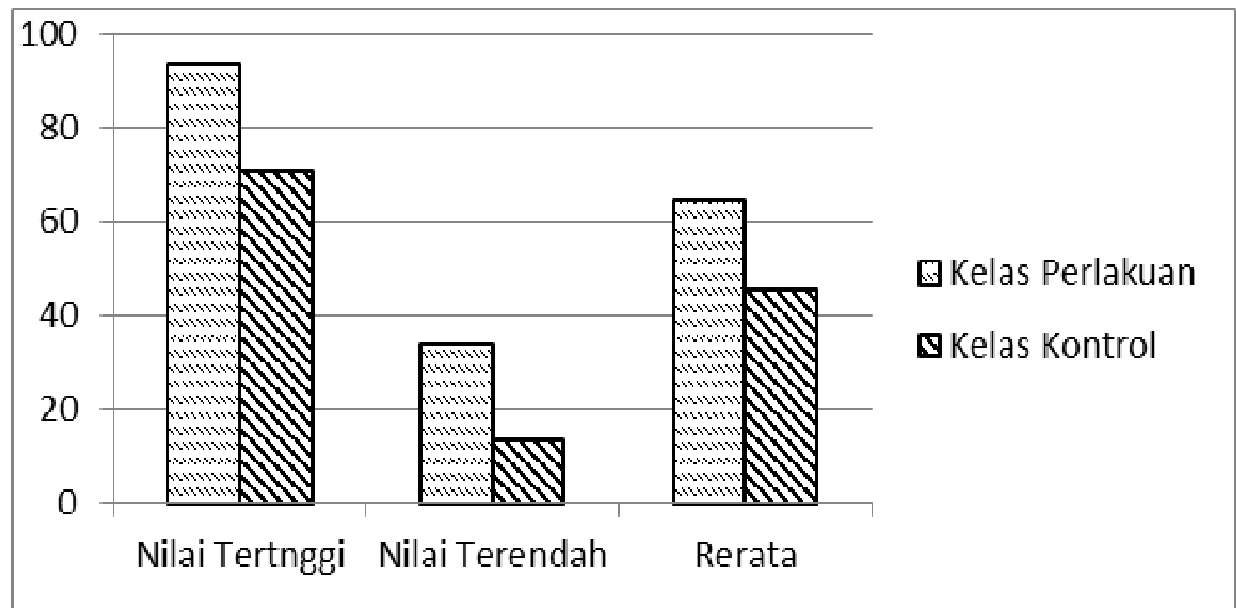

Gambar 1. Retensi Nilai Tertinggi, Nilai Terendah dan Rerata

Data hasil retensi pada empat retensi postes pada setiap indikator secara indikator penialian, meliputi proporsi, ringkas pada Tabel 4 . hierarki, kaitan silang dan contoh. Nilai

Tabel 4. Nilai Rerata Retensi pada Setiap Indikator

\begin{tabular}{|c|c|c|c|c|c|c|}
\hline \multirow{2}{*}{ Indikator } & \multicolumn{2}{|c|}{ Kelas Perlakuan } & \multirow{2}{*}{$\begin{array}{c}\text { Peningkatan } \\
\text { (\%) }\end{array}$} & \multicolumn{2}{|c|}{ Kelas Kontrol } & \multirow{2}{*}{$\begin{array}{c}\text { Peningkatan } \\
(\%)\end{array}$} \\
\hline & Fitohormon & Gerak & & Fitohormon & Gerak & \\
\hline Proporsi & 14,69 & 18,96 & 4,27 & 14,30 & 18,47 & 4,16 \\
\hline Hierarki & 3,65 & 5,33 & 1,65 & 3,74 & 5,13 & 1,39 \\
\hline Kaitan Silang & 1,96 & 2,73 & 0,78 & 2,57 & 2,93 & 0,37 \\
\hline Contoh & 0,13 & 0,73 & 0,57 & 0,13 & 0,87 & 0,74 \\
\hline Total & & 48,13 & & & 48,14 & \\
\hline
\end{tabular}

Terdapat selisih yang cukup jauh nilai yang diperoleh kelas kontrol. Hal ini dipengaruhi oleh minat yang kurang dalam melaksanakan test mind map, dikarenakan sebagian dari peserta didik didik tidak membawa leptop saat test dilakukan, sehingga waktu yang digunakan terbuang dengan saling bergantinya peserta didik menggunakan leptop teman yang membawa, dan kurang pahamnya peserta 
didik dalam mengoperasikan program Edraw Mind Map versi 7 dengan baik, sehingga waktu tersita.

Kemampuan peserta didik dalam menghubungkan konsep pada kelas perlakuan cukup tinggi, hal ini dikarenakan dalam strategi konversi peta konsep pada penyusunan peta konsep dan indikator penilaian retensi terdapat kaitan silang, dimana peserta didik dibiasakan untuk menghubungkan satu konsep dengan konsep yang lain sehingga menjadi suatu konsep materi yang dipahami secara utuh. Hal ini diperkuat oleh pendapat Novak, J.D. et al (1983), suatu gambaran skematis untuk mempresentasikan suatu rangkaian konsep yang berkaitan antar konsepkonsep. Peta ini mengungkapkan hubungan-hubungan yang berarti antara konsep dan menekankan gagasan-gagasan pokok.Peta konsep disusun hirarkis, konsep yang lebih umum berada di atas dalam peta itu, sedangkan yang khusus di bawah.

Adapun indikator yang diukur dalam penilaian retensi yaitu :

1) Proposisi, dua konsep yang dihubungkan oleh kata penghubung. Proposisi dikatakan sahih jika menggunakan kata penghubung yang tepat. Berdasarkan data diperoleh bahwa pada kelas perlakuan. Diperoleh dari data pada kelas perlakuan materi fitohormon adalah 14,69, dan gerak tumbuhan adalah 18,96 dengan peningkatan sebesar 4,27. Sedangkan pada kelas kontrol materi fitohormon diperoleh sebesar 14,30 dan gerak tumbuhan sebesar 18,47 dengan peningkatan 4,16. Maka peningkatan pada kelas perlakuan dan kontrol tidak jauh beda, yaitu bekisar 4 $\%$, dengan perbedaan 0,11 point, dan peningkatan yang tinggi terdapat pada kelas perlakuan.

2) Hierarki, tingkatan dari konsep yang paling umum sampai konsep yang paling khusus. Urutan penempatan konsep yang lebih umum dituliskan di atas dan konsep yang lebih khusus dituliskan di bawahnya. Hierarki dikatakan sahih jika urutan penenmpatan konsepnya benar. Berdasarkan data diperoleh bahwa pada kelas perlakuan materi fitohormon adalah 3,65 dan materi gerak tumbuhan adalah 5,33 , dengan peningkatan 1,65. Sedangkan pada kelas kontrol materi fitohormon diperoleh sebesar 3,74 dan gerak tumbuhan sebesar 5,13 dengan peningkatan 1,39 Maka peningkatan pada kelas perlakuan dan kontrol tidak jauh beda, yaitu bekisar $1 \%$, dengan perbedaan 0,34 point, dan peningkatan yang tinggi terdapat pada kelas perlakuan.

3) Kaitan silang, hubungan yang bermakna antara suatu konsep pada satu hierarki dengan konsep lain pada hierarki yang lainnya. Kaitan silang dikatakan sahih jika menggunakan kata penghubung yang tepat dalam menghubungkan kedua konsep pada hierarki yang berbeda. Berdasarkan data diperoleh bahwa pada kelas perlakuan materi fitohormon adalah 1,96 dan materi gerak tumbuhan adalah 0,78 , dengan peningkatan 0,78 . Sedangkan pada kelas kontrol materi fitohormon diperoleh sebesar 2,57 dan gerak tumbuhan sebesar 2,934 dengan peningkatan 0,37 Maka peningkatan pada kelas perlakuan dan kontrol tidak jauh beda, yaitu bekisar $0 \%$, dengan perbedaan 0,43 point, dan peningkatan yang tinggi terdapat pada kelas perlakuan.

4) Contoh, adalah kejadian atau objek yang spesifik yang sesuai dengan atribut konsep. Contoh dikatakan sahih jika contoh tersebut tidak dituliskan di dalam kotak karena 
contoh bukanlah konsep. Berdasarkan data diperoleh bahwa bahwa pada kelas perlakuan materi fitohormon adalah 0,13 dan materi gerak tumbuhan adalah 0,78 , dengan peningkatan 0,57. Sedangkan pada kelas kontrol materi fitohormon diperoleh sebesar 0,13 dan gerak tumbuhan sebesar 0,87 dengan peningkatan 0,74 Maka peningkatan pada kelas perlakuan dan kontrol tidak jauh beda, yaitu bekisar $0 \%$, dengan perbedaan 0,23 point. Dimana kelas kontrol memiliki peningkatan dibanding kelas perlakuan pada indikator pemberian contoh. Berdasarkan total penilaian setiap indikator pada kelasperlakuan dengan kontrol tidak tidak terdapat perbedaan yang signifikan.

Retensi belajar mahasiswa yang diperoleh pada pretest dan posttestmateri fitohormon, dan gerak tumbuhan baik kelas perlakuan dan kelas kontrol, maka data retensi tersebut terlebih dahulu harus di ketahui normalitas, dan homogenitasnya.
1) Uji Normalitas

Uji normalitas data retensi dianalisis dengan menggunakan KolmogorovSmirnov Test dibantu dengan program SPSS 21 for Windows didapatkan kelas perlakuan 0,673 dan kelas kontrol diperoleh 0,330. Jika nilai probabilitas Sig. Kolmogorov-Smirnov Z $\quad 0,673$; $0,330>0,05$, maka $\mathrm{H}_{0}$ diterima, artinya data terdistribusi normal.

2) Uji Homogenitas

Uji homogenitas dilakukan apabila data berdistribusi normal, yang dianalisis menggunakan uji Levens.Secara umum sebaran dataretensi 0,673, Jika nilai probabilitas Sig. Homogeneity of Variances Levens 0,673 >0,05, maka $\mathrm{H}_{0}$ diterima artinya data varians adalah homogen.Penjelasan ringkas hasil normalitas dan homogenitas retensi belajar mahasiswa pada Tabel 5.

Tabel 5. Normalitas dan Homogenitas Retensi

\begin{tabular}{ccc}
\hline \multirow{2}{*}{ Kelas } & \multicolumn{2}{c}{ Retensi } \\
\cline { 2 - 3 } & Normalitas & Homogenitas \\
\hline Perlakuan & 0,673 & 0,330 \\
Kontrol & 0,240 & 0,242 \\
\hline Kategori & Normal & Homogeny \\
\hline
\end{tabular}

3) Uji t

Pengujian hipotesis dilakukan untuk untuk mengetahui pengaruh perbedaan pembelajaran, antara kelas perlakuan, yaitu strategi konversi peta konsep dan kelas kontrol, multistrategi terhadap retensi, maka diperoleh hasil analisis ringkas pada Tabel 6.

Tabel 6. Ringkasan Retensi Uji T Terhadap retensi

\begin{tabular}{|c|c|c|c|c|c|c|c|}
\hline \multirow{2}{*}{ Source } & \multicolumn{2}{|c|}{$\begin{array}{c}\text { Levene's Test for } \\
\text { Equality of Variances }\end{array}$} & \multicolumn{5}{|c|}{ t-test for Equality of Means } \\
\hline & $F$ & Sig & $t$ & $d f$ & $\begin{array}{l}\text { Sig. (2- } \\
\text { tailed) }\end{array}$ & $\begin{array}{c}\text { Mean } \\
\text { Difference }\end{array}$ & $\begin{array}{l}\text { Std. Error } \\
\text { Difference }\end{array}$ \\
\hline $\begin{array}{l}\text { Equal variances } \\
\text { assumed }\end{array}$ & 0,233 & 0,631 & 4,322 & 60 & 0,00 & 19,67 & 4,543 \\
\hline $\begin{array}{l}\text { Equal variances } \\
\text { not assumed }\end{array}$ & & & 4,304 & 56,13 & 0,00 & 19,67 & 4,772 \\
\hline
\end{tabular}


Berdasarkan hasil uji t pada Tabel 6 pengaruh variabel bebas terhadap retensi diperoleh angka signifikansi (2 tailed) $=$ 0,000 (Sig. $<0,05$ ) , maka $\mathrm{H}_{0}$ ditolak. Sehingga pada kepercayaan $95 \%$, terdapat pengaruh strategi konversi peta konsepterhadap retensi. Hal ini sejalan dengan Herlanti K. (2005), yang melaporkan bahwa retensi siswa pada kelompok multimedia lebih tinggi dari pada kelompok non multimedia pada materi hereditas, yang menandakan tampilan tampilan multimedia yang mempunyai kekuatan imagery, terbukti mampu menyimpan lebih lama abstraksi-abstraksi konsep di dalam struktur kognitif siswa. Begitupun hasil penelitian Manurung, B. et al (2015). Terdapat perbedaan yang signifikan pada retensi terhadap penggunaan video belajar dibanding dengan media animasi, dan, charta. Namun bila dilihat berdasarkan mean diffetence tidak terdapat antara retensi kelas perlakuan dengan kelas kontrol. Hal ini disebabkan salah satunya penguatan pemahaman konsep dalam belajar Fisiologi tumbuhan menggunakan media video dan slide power point.

Hal ini sejalan dengan penelitian Miller (Suyatna, A. ; 2008), yang menyatakan bahwa video sebagai media pembelajaran memiliki beberapa kelebihan antara lain dapat dilihat dan didengar secara berulang, memberi stimulus secara simultan terhadap berbagai indera (melihat dan mendengar), serta membantu kejelasan informasi dan memori / retensi. Hal ini juga sejalan dengan Herlanti (2005), yang melaporkan bahwa retensi siswa pada kelompok multimedia lebih tinggi dari pada kelompok non multimedia pada materi hereditas, yang menandakan tampilan tampilan multimedia yang mempunyai kekuatan imagery, terbukti mampu menyimpan lebih lama abstraksi-abstraksi konsep di dalam struktur kognitif siswa. Begitupun hasil penelitian Manurung, Binari, dkk.(2015), Terdapat perbedaan yang signifikan pada retensi terhadap penggunaan video belajar dibanding dengan media animasi, dan, charta.

\section{KESIMPULAN}

Berdasarkan hasil analisis data retensi diperoleh angka signifikansi (2 tailed) = 0,000 (Sig. $<0,05$ ), maka $\mathrm{H}_{0}$ ditolak. Sehingga pada kepercayaan 95\%, terdapat pengaruh strategi konversi peta konsep terhadap retensi, maka kesimpulan yang didapatkan dari penelitian ini adalah ada pengaruh strategi konversi peta konsep terhadap retensi peserta didik kelas IV C Jurusan Pendidikan IPA Biologi UIN Mataram Tahun Ajaran 2016-2017. Berdasarkan penelitian yang telah dilakukan, saran yang dapat diajukan yaitu (1) Pembelajaran strategi konversi peta konsep sangat berpotensi dalam memberdayakan retensi. Oleh karena itu disarankan bagi pengajar (guru maupun dosen) untuk menerapkan pembelajaran strategi konversi peta konsep, (2) Pembelajaran strategi konversi peta konsep selain memberdayakan retensi, , juga berpotensi untuk mengembangkan pemahaman konsep, kemampuan berpikir kritis, hasil belajar dan motivasi peserta didik, dan (3) Penerapan strategi konversi peta konsep sangat disarankan dalam pembelajaran Kurikulum 2013 yang berpotensi dalam memberdayakan keaktifan peserta didik, serta hasil belajar pada ranah kognitif, psikomotorik, dan afektif.

\section{UCAPAN TERIMA KASIH}

Lembaga Penelitian dan Pengabdian Masyarakat (LP2M) dan Pusat Pengabdian 
Kepada Masyarakat (P2M) UIN Mataram, selaku lembaga yang memfasilitasi peneliti dalam pembiayaan sehingga penelitian ini dapat terlaksana.

\section{DAFTAR PUSTAKA}

Adtya, D. M. 2015. "Penerapan Mindmap Conversion Back To BackBerbasis Lesson StudyUntuk Meningkatkan Pemahaman Konsep, Retensi Peserta didik Jurusan Biologi Pada Matakuliah Fisiologi Tumbuhan". Prosiding Seminar Nasional Pendidikan Biologi, Universitas Muhamadiyah Malang.

Asyhar, H. Rayandra. (2012) Kreatif Mengembangkan Media Pembelajaran.Jakarta: Referensi

Cheppy Riyana. 2007. http://www.scribd.com /doc/54656100/Fungsi-Manfaat-DanKegunaan-Media-Pembelajaran. Diambil Pada (27/0413) 10:49

Dwijoseputro, D. 1978. Pengantar Fisiologi Tumbuhan, Jakarta: PT.Gramedia. Jakarta; PT. Elek Media Komputindo

Francis M. Dwyer. 1978. Strategies for Improving Visual Learning. A Handbook for the effective selection, design, and use of visualized materials. H.215.
Ginnis, P. 2008. Trik dan Taktik Mengajar, Strategi Meningkatkan Pencapaian Pengajaran di Kelas, Jakarta : PT. Indeks.

Herlanti K. 2005. Analisis dan Pemahaman Retensi Siswa SMP, Penggunaan Wacana Multimedia "Berpetualangan Bersama Mendel". (Kajian Terhadap Teori Reduksi Didaktif dan Pedagogi Materi Subyek). Tesis SPS UPI Bandung. Tidak Diterbitkan.

Manurung, B. et al. 2015. Pengaruh Penggunaan Media TIK Terhadap retensi Memori Biologi Siswa Kelas XII SMA. Jurnal Pendidikan dan Pembelajaran (JPP) Vol.22 No.2.

Novak, J.D. et al. 1983. The Use Of Concept Mapping And Vee Mapping With Junior High School Science Students. Science Education; h. 67.

Paul Legrand, 1970. An introduction to Lifellong Education. United Nations Educational, Scientific and Cultural Organazation Document Series ED Vol. 70: 56

Suyatna,A. 2008. Pemanfaatan multimedia untuk Pembelajaran Sains Bermuatan Nilai. Prosiding : Seminar Nasional Sains, Universitas Lampung.

Suyono. 2011. Belajar dan Pembelajaran. Bandung: PT. Remaja Rosdakarya. 